\title{
Biber hafif benek virüs'üne (PMMoV) karşı L4 dayanıklılık durumunun taranması ve moleküler yöntemlerle karakterizasyonu
}

\author{
Screening of L4 resistance status to pepper mild mottle virus (PMMoV) and \\ characterization by molecular methods
}

\author{
Hakan FIDAN@, Murat BARUT(i) \\ Akdeniz Üniversitesi, Ziraat Fakültesi, Bitki Koruma Bölümü, Antalya \\ Sorumlu yazar (Corresponding author): H. Fidan, e-posta (e-mail): hakanfidan@akdeniz.edu.tr \\ Yazar(lar) e-posta (Author e-mail): murab07@gmail.com
}

\section{MAKALE BİLGİSİ}

Alınıs tarihi 19 Temmuz 2019

Düzeltilme tarihi 05 Eylül 2019

Kabul tarihi 05 Eylül 2019

\section{Anahtar Kelimeler:}

L4 geni

Dayanıklılı̆̆ın kırılması

Biber

Biber hafif benek virüsü

PMMoV

\begin{abstract}
$\ddot{O Z z}$
Biber hafif benek virüsü (Pepper mild mottle virus- PMMoV) Tobamovirüsler içerisinde yer alan dünya genelinde biber üretim alanlarında en sık karşılaşılan virüslerden biridir. Bu virüs çoğu zaman hasat dönemine kadar gizli kalabilmekte ve en büyük zararlarını hasat döneminde meyveler üzerinde meydana getirebilmektedir. Bölgemizde son yıllarda biber üretim alanlarında sıklıkla karșılașılan bir problem olarak karșımıza çıkmaktadır. Dünyanın farklı bölgelerinde L4 geni vasıtasıyla sağlanan dayanıklılığı kıran virüs izolatının rapor edilmesi, ülkemizde de PMMoV'nin epidemi durumunun araştırılması gerekliliğini ortaya koymuştur. L4 dayanıklılığının etkinliğini belirleyebilmek için bölgemizden biber üretim alanlarında PMMoV ile şüpheli örnekler toplanmıştır. RT-PCR tekniği ile doğrulanan bu örnek PMMoVKum olarak kodlanmıștır ve Gen bankasına kaydı yapılarak erișim numarası (MK806437) alınmıştır. PMMoV-Kum izolatı 1 hassas (B1) ve 5 dayanıklı (L4B1, L4B2, L4B3, L4B4, L4B5) bitkilerine mekanik inokulasyon yöntemi ile bulaştırılmıştır. Yapılan fenotipik gözlemler neticesinde PMMoV-Kum izolatının L4 genine bağlı dayanıklılı̆ı kıramadığı biyolojik testler ile doğrulanmıştır. Dayanıklı olarak seçilen bitkiler üzerinde herhangi bir PMMoV simptomunun olușmaması üzerine en bașarılı çalıșan L4 markırlarını belirlemeye yönelik primerlerin belirlenmesi tez çalışmasının seyrini belirlemiş ve en başarılı markırın AP7/AP-8 ve P118/119primer çiftleri olduğu tespit edilmiştir.
\end{abstract}

\section{ARTICLE INFO}

Received 19 July 2019

Received in revised form 05 September 2019

Accepted 05 September 2019

\section{Keywords:}

L4 gene

Resistance Breaking

Pepper

Pepper mild mottle virus

PMMoV

\begin{abstract}
Pepper mild mottle virus (PMMoV) is one of the most common Tobamoviruses can be found in worldwide. This virus has potential to cause economic losses and has kept secret infections until harvest time causing great damages on pepper fruits at this period. During 2016-2019 production periods, it has been frequently seen in pepper grown areas. Several isolates reported from different regions of the world regarding resistance with $L A$ gene fights against this virus disease. In this study, we aimed to investigate how the PMMoV increased and understood its incidence pepper grown areas in Turkey. In order to determine the effectiveness of $L 4$ resistance, PMMoV and other suspected pepper samples were isolated. The collected samples were studied by RT-PCR technique using PMMoV-Kum isolate and its gene bank's access number (MK806437) was registered. A sensitive (B1) and 5 resistant (L4B1, L4B2, L4B3, L4B4, L4B5) plants were mechanically inoculated with the PMMoV-Kum isolate and their phenotypic observations were recorded. The PMMoV-Kum isolate was confirmed as avirulent in biological tests, the PMMoV could not overcome $L 4$ gene mediated resistance. Furthermore, a successful primer set has determined as AP-7 / AP-8 in L4 gene mediated resistance against occurrence of any PMMoV symptoms on the tested plants. Determining new PMMoV isolates which break the $L 4$ gene mediated resistance, phylogenetic analyzes was performed to determine its place among the world's isolates.
\end{abstract}




\section{Giriş}

Biber (Capsicum annuum L.) dünyada en yaygın olarak üretilen ve tüketilen aynı zamanda ekonomik olarak önemli yere sahip sebze gruplarından biridir. FAO 2017 yılı verileri incelendiğinde dünya genelinde 34655.814 ton biber üretimi yapıldığı rapor edilmiştir (FAOSTAT 2018). Ülkemizde de yoğun olarak tarımı yapılan biber bitkisi TUIKK 2018 verileri temel alındığında, Antalya ve ilçelerinin toplam 439.255 ton ile ilk sırada yer aldığı görülmektedir. Biber ülkemizde SalçalıkKapya, Dolmalık, Sivri ve Çarliston çeşitleri olarak üretimi gerçekleştirilmekte olup, bu ürün grupları içerisinde 187.311 ton ile Sivri çeşidi en fazla üretimi yapılan biber çeşidi olarak karşımıza çıkmaktadır (TUİK 2018).

Biber yetiştiriciliği yapılan açık alan ve seralarda üretim verilerini sınırlandıran birçok faktör karşımıza çıkmaktadır. Biber yetiştiriciliği yapılan alanlarda hem kaliteyi hem de üretim miktarını etkileyen en önemli parametrelerin başında virüs hastalıkları gelmektedir (Anandakumar ve ark. 2008). Üretim alanlarında en sık karşılaşılan vektörler; yaprak bitleri (Myzus persica), thripsler (Thrips tabaci, Frankliniella occidentalis) ve beyazsinekler (Bemisia tabaci) olarak bilinmektedir ve bu vektörler önemli verim kayıplarına sebep olan virüslerin taşınımında etkin rol oynamaktadır. Bazı araştırmacılar biber üretim alanlarında sık rastlanan ve önemli olan ilk üç virüs olarak; Potato virus $Y$ (PVY), Tomato Spotted wilt virus (TSWV) ve Pepper mild mottle virus (PMMoV) olduğunu belirtmişlerdir (Kim ve ark. 2008; Janzac ve ark. 2009; Scholthof ve ark. 2011). Fakat, Biber hafif benek virüsü'nün de (PMMoV) dahil olduğu Tobamoviruslerin bilinen bir vekörü olmamasına rağmen temas ile bulaşabilmeleri nedeniyle üretim alanlarının en büyük sorunları olarak karşımıza çıkmaktadır. Virüs hastalıkları ile mücadelede en başarılı yönetim modeli, dayanıklı çeşitlerin ıslahı ve bu hastalıklara vektörlük yapan böceklere karşı kültürel-kimyasal mücadele yöntemlerinin kullanılmasıdır. Birçok virüs vektörü ile kimyasal-kültürel mücadeleler yapılarak hastalık kontrol altında tutulabilmektedir. Fakat daha büyük sorun ise, Tobamovirusler gibi temas yoluyla bile rahatlıkla bulaşabilen ve şu ana kadar vektörü tespit edilmeyen ya da edilemeyen virüslerin varlığıdır. Virülensliği çok yüksek olan bu virüslerin mücadelesi bir o kadar zor olmaktadır.

Son zamanlarda hem üreticiler ve hem de islah firmaları tarafindan, PMMoV ile ilgili şikâyetlerin arttığı tespit edilmiştir. Yürütmüş olduğumuz bu çalışma ile de bu şikâyetlerin nedenleri ve $L 4$ ile sağlanan dayanımın kırılıp kırılmadığının tespit edilmesi yolu izlenmiştir. Kimyasal, fiziksel ve kültürel yöntemler, PMMoV kontrolünde bir yere kadar başarı sağlayabildiği için, dayanıklı çeşitlerin geliştirilmesi en önemli kontrol stratejisi olarak kabul edilmektedir. Tobamoviruslere karş1 dayanıklılıkta kullanılan L lokusu Capsicum türlerinin yabani ve kültür formları, Capsicum annuиm (L1), Capsicum frutescens (L2), Capsicum chinense (L3) ve Capsicum chacocense (L4) de bulunmuştur (Boukema 1980; BerzalHerranz ve ark. 1995). PMMoV'ye karşı dayanıklılık Ll'den L4'e kadar siralanabilen 4 adet dayanıkl1lık geni tarafindan sağlanmaktadır (Boukema 1984). L genleri aracılığ 1 ile Tobamoviruslerin $\mathrm{P} 0, \mathrm{P} 1, \mathrm{P} 1.2$ veya $\mathrm{P} 1.2 .3$ patotipleri üzerinde dayanıklılık sağladığı belirlenmiştir (Csillery ve ark. 1983; Pernezny ve ark. 2003; Wetter ve ark. 1984). P0 patotipine ait virüsler, herhangi bir $L$ geni taşıyan bitkilere bulaşamaz. Benzer bir şekilde virüslerin ait olduğu $\mathrm{P} 1, \mathrm{P} 1.2$ ve P1.2.3 patotipleri sistematik olarak sirasiyla $L 1$ ve $L 1 a$ genlerini; $L 1$ ve $L 2$ genlerini ve $L 1$ ile $L 3$ genlerini enfekte edebilmektedir (Sawada ve ark. 2005). Bu sinıflandırmaya uygun olarak da dünyada bulunan PMMoV izolatları P1.2 veya P1.2.3 olarak adlandırılmıştır (Rast 1988). L3 genini taşıyan bitkiler patotip P1.2'ye dayanıklıdır, fakat P1.2.3'e karşı hassastır (Matsunaga ve ark. 2003). Aksine, L4 genine sahip bitkiler her iki patojene karşıda dayanıklıdır (Matsunaga ve ark. 2003; Kim ve ark. 2008).

Ülkemizde de Tobamoviruslere karşı dayanıklılık da $L 3$ ve L4 genleri etkin bir şekilde kullanılmaktadır. Yoğun biber tarımı yapılan alanlarda PMMoV ile karşılaşılması sonucunda bu gen vasıtasıyla dayanıklılığın kırılıp kırılmadığı akıllarda soru işaretleri oluşturmaktadır. Yürütmüş olduğumuz bu çalışma ile üretim alanlarında kullanılan biber çeşitleri üzerinde $L 4$ genlerinin varlığı moleküler markırlar yardımıyla belirlenmiştir. L4 geni içeren bitkilerde PMMoV mekanik olarak bulaştırılmış ve $L 4$ dayanıklılığının kırılmadığı belirlenmiştir. $L 4$ geni kullanılarak yürütülen sslah çalışmalarında araştırmacılara başarılı bir yol haritası sağlamak amacıyla rapor edilen markırlar denenmiştir. Gerçekleştirmiş olduğumuz çalışma ile hem L4 geninden kaynaklı dayanıklılığın kırılmadığ belirlenmiş ve bu genin varlığının tespitinde en başarılı şekilde sonuç veren moleküler markırın tespiti yapılarak araştırmacılara sunulması hedeflenmiştir.

\section{Materyal ve Metot}

Yürütülen çalışma esnasında kullanılan PMMoV izolatı Antalya bölgesinde yoğun biber tarımının yapıldığ 1 Kumluca ilçesinde bulunan seralardan temin edilmiştir. PMMoV izolatının L4 geni vasıtasıyla sağlanan dayanıklılığının üstesinden gelip gelmediğini belirleyebilmek için 1 adet hassas (B1) ve 5 adet ticari olarak $L 4$ geni barındırdığ çeşit (L4B2, L4B3, L4B4, L4B5, L4B6) test bitkisi olarak kullanılmıştır. Bitkilere deneme süresi boyunca 7 gün aralıklarla thrips, beyazsinek, kırmızı örümcek ve yaprakbiti ilaçları uygulanmıştır. Sulama suyu olarak $18.18 .18+2 \mathrm{Mg}+\mathrm{ME}$ gübreli su kullanılmıştır. Deneme hem serada hem de iklim odasında 5 tekerrürlü olarak kurulmuştur. Denemeler esnasında sera içinde herhangi bir suni 1şıklandırma veya 1sıtma yapılmamıştır. İklim odasında ise bitkiler flüoresan lambalarla 1şıklandırılmış (16 saat aydınlık, 8 saat karanlık) ve iklim odasının sıcaklığ $25^{\circ} \mathrm{C}$ 'de tutulmuştur.

Biberler üzerinde PMMoV'ye karşı mücadelede en etkin yöntem $L 4$ geninin kullanılması ve etkin bir biçimde moleküler markırlar ile belirlenebilmesidir. L4geninin varlığını tespit edebilmek için DNA ekstraksiyonu GeneJET Plant Genomic DNA Purification Kit kullanılarak gerçekleştirilmiş̧ir. Ekstraksiyon çalışması sonucunda elde edilen DNA'ların konsantrasyonları belirlenmiştir. Her bir örnek için PCR bileşenleri için; DreamTaq Green PCR Master Mix (2X) (Thermo Scientific,K1081,Germany), $11 \mu 1$, Forward primer 1.0 $\mu \mathrm{M}$, Reverse primer $1.0 \mu \mathrm{M}$, Template DNA $10 \mathrm{pg}-1 \mu \mathrm{g}$, steril distile su $11 \mu \mathrm{l}$ olarak belirlenmiştir. Bu amaç doğrultusunda 6 test bitkisi, biberde $L 4$ geninin tespitinde yayınlanmış ve kabul gören primerler; L4SC340 (Kim ve ark. 2008), AP-7/AP-8 (Matsunaga ve ark. 2003), 060I2END- 087H3T7 (Yang ve ark. 2009), P118/P119 (Lefebvre ve ark. 2002) ile test edilmiştir. Kullanılan primerlere ait bilgiler Çizelge 1'de verilmiştir.

Yürütülen çalışma sırasında kullanılan biber bitkileri Akdeniz Üniversitesi Fitopatoloji seralarında muhafaza edilmiştir. Mekanik inokulasyon çalışmaları için \%0.1 2mercaptoethenol içeren $0.02 \mathrm{M}$ Fosfat tampon çözeltisi (pH: 7) 
Çizelge 1. L4 dayanımını belirlemek için kullanılan primerlere ait bilgiler.

Table 1. Information on primers used to determine L4 gene.

\begin{tabular}{|c|c|c|c|c|}
\hline Marker & Primer İsmi & Primer dizilimi 5' 3' & Boyut(Bç) & Annelig \\
\hline \multirow[t]{2}{*}{ 087H3T7 } & 087H3T7F & CCTTTGCCTGCATTATTCTTG & 440 & 62 \\
\hline & 087H3T7R & GCCCAAATTTATTCCCAAATGC & & \\
\hline \multirow[t]{2}{*}{ 060I2END } & 060I2END-2F & GCACATCAGCAGGTTTAGTACG & 751 & 62 \\
\hline & 060I2END-2R & CCAACTGTCAAACCTCGG & & \\
\hline \multirow[t]{2}{*}{ L4SC340 } & L4SC340F & AAGGGGCGTTCTTGAGCCAA & 340 & 53 \\
\hline & L4SC340R & TCCATGGAGTTGTTCTGCAT & & \\
\hline \multirow[t]{2}{*}{ AP-7/AP-8 } & AP-7 & CGTACTGTGGCTCAAAACTC & 1400 & 58 \\
\hline & AP-8 & ATTCGCACCGTTTAGCCCGT & & \\
\hline \multirow[t]{2}{*}{ P118/P119 } & P118 & AATCCTTCAACTGCCATTTC & 350 & 58 \\
\hline & P119 & ATTGGGACATGAGGTGTGTA & & \\
\hline
\end{tabular}

1:5 (w/v) oranında kullanılmıştır. PMMoV izolatı porselen havanda ezilmiștir. Bitkilerin farklı sıcaklık ve ortamlarda virüse karşı gösterdikleri dayanıklılık cevaplarını inceleyebilmek için bitkiler üzerinde farklı dönemlerde mekanik inokulasyon işlemleri gerçekleştirilmiştir. Her dönem için bitkilere 5'er kez mekanik inokulasyon işlemi yapılmıştır. Simptomların hassas çeşitler üzerinde gelişmesiyle birlikte virüsün varlığını doğrulayabilmek adına RT-PCR çalışmaları gerçekleştirilmiştir.

L4 geninin varlığı moleküler olarak karakterize edildikten sonra bu bitkilerden yaprak örnekleri alınarak RT-PCR çalışmalarında kullanabilmek için Thermo Scientific- RNA izolasyon kiti (Thermo Scientific,K0731, Germany), ile bitkilerden RNA izolasyonu gerçekleştirilmiştir. Elde edilen RNA'lar spektrofotometrede optimize edilerek (A260/280 1.82.0) konsantrasyonları $200 \mathrm{ng} / \mu \mathrm{l}$ olacak şekilde ayarlanmıştır. RNA optimizasyonu yapıldıktan sonra Thermo Scientific Verso 1-Step RT-PCR Kit ReddyMix kullanılarak tek aşamalı RTPCR (One Step RT-PCR) çalışmaları yürütülmüştür. Her bir örnek için RT-PCR bileşenleri, Verso Enzim Mix 0.5 $\mu 1,2 X-1$ Step PCR ReddMix* $12.5 \mu 1$, RT Enhanser $1.25 \mu 1$, Forwrd primer $1 \mu \mathrm{l}$, Reverse primer $1 \mu \mathrm{l}$, RNA $2 \mu \mathrm{l}$, dd $\mathrm{dd}_{2} \mathrm{O} 6.25 \mu \mathrm{l}$ toplamda $25 \mu$ l olacak şekilde ayarlanmıştır. Simptomların sadece PMMoV'ye ait olduğunun tespit edilebilmesi için Fidan ve Sarı (2019)'a göre üretim alanlarında en sık rastlanan virüs hastalıklarına karşı RT-PCR çalışmaları yapılmış ve elde edilen izolatın sadece PMMoV olduğu doğrulanmıştır. Elde Edilen RT-PCR ürünleri \%1.5 lik agaroz jel de yürütülmüş Ethidium bromide ile boyandıktan sonra Biometra jel görüntüleme cihazında UV altında görüntülenmiştir.

Velasco ve ark. (2002) PMMoV'yi tanılamak amaciyla geliştirdikleri primerleri kullanılarak PMMoV-Kum izolatının replikasyon proteini üzerindeki 4015-4807 aralığının (183 kDa bölgesi) ampifikasyonu yapılarak genom bilgileri elde edilmiştir. Elde edilen veriler soy ağacının oluşturulması aşamasında kullanılmıştır. $\mathrm{Bu}$ amaçla RT-PCR'da $50 \quad \mu 1$ hacimde çalışılarak $10 \mu \mathrm{l}$ 'lik hacim jelde yürütülmüş ve $40 \mu$ l'lik kalan kısmı dizileme hizmeti almak için gönderilmiştir. Dizilemede Sentebiolab firmasından hizmet alımı gerçekleştirilmiştir. Dizileme sonucunda elde edilen veriler CHROMAS v.2.6.4 (Technelysium Pty. Ltd.), BIOEDIT v.7.2.5 (Hall 1999) ve Mega7 (Kumar ve ark. 2011) programları kullanılarak analiz edilmiştir. CHROMAS programı ile yaklaşık $806 \mathrm{bp}$ uzunluğunda olan ürünlerin forward ve reverse dizilerinin baş ve son kısımlarındaki okuma kirlilikleri silinmiştir. Daha sonra forward ve reverse dizileri BIOEDIT programında üst üste denk getirilerek okuma doğrulanmış ve olası baz kaymaları düzeltilmiştir. Çalışmaya ait olan tüm hizalama (alignment) ve filogenetik analizler MEGA7 programı ile yapılmıştır.

\section{Bulgular ve Tartışma}

Biber hafif benek virüsü (PMMoV) biber üretim alanlarında ekonomik anlamda zarar meydana getiren en önemli virüslerden biridir. Yapılan bu çalışma ile de PMMoV'ye karşı L4 vasıtasıyla sağlanan dayanıklılık durumları belirlenmeye çalışılmıştır. L4 genin aktivasyonunu belirleyebilmek için 1 hassas (B1) ve 5 adet ticari olarak $L 4$ geni barındırdığı beyan edilen çeşit (L4B2, L4B3, L4B4, L4B5, L4B6) test bitkisi olarak kullanılmıştır. Bitkiler üzerinde L4 geninin varlığının tespit edilmesi için; yayınlanmış ve kabul gören primerler; L4SC340 (Kim ve ark. 2008), AP-7/AP-8 (Matsunaga ve ark. 2003), 060I2END- 087H3T7 (Yang ve ark. 2009), P118/P119 (Lefebvre ve ark. 2002) kullanılmıştır ve Şekil 1'de PCR çalışmasının sonuçları paylaşılmıştır. Yapılan analizler doğrultusunda AP-7/AP-8 primerlerinin L4 dayanımını belirlemede en güvenilir sonucu veren primer çifti olduğu tespit edilmiştir.

Test bitkilerinin PMMoV'ye karşı tepkilerinin belirlenmesi amaciyla virüs, bitkilere mekanik inokulasyon yöntemi kullanarak bulaştırılmıştır. Bulaştırma sonucunda elde edilen bulgular doğrultusunda $L 4$ geninin PMMoV'a karşı dayanıklılık durumları fenotipik ve genotipik gözlemler kullanılarak belirlenmiştir. Bitkilerde ilk simptomlar hassas çeşitlerde gözlemlenmiştir ve $L 4$ geni var olduğu beyan edilen çeşitlerde ise HR (hipersensetif reaksiyon)'lar ortaya çıkmıştır. Farklı dönemlerde kurulan denemelerde PMMoV-Kum izolatı sadece hassas çeşit olarak seçilen B1 bitkisi üzerinde sistemik enfeksiyonlar oluştururken, L4 geni içeren çeşitler üzerinde herhangi bir sistemik enfeksiyon meydana getirmediği belirlenmiştir (Şekil 2).

L4 genin farklı sıcaklıklarda verdiği reaksiyonlarının da belirlenebilmesi amaciyla bu deneme 5 farklı dönemde; biber bitkilerinin farklı ortamlarda (iklimlendirme odaları ve sera) ve farklı sıcaklık dönemlerde (ilkbahar, yaz, sonbahar ve kış periyodlarında) PMMoV enfeksiyonlarına karşı verdikleri tepkiler belirlenmiştir. $\mathrm{Bu}$ amaç doğrultusunda oluşturulan plan Çizelge 2'de ve bitkilerin her dönem PMMoV izolatı ile enfekteli olma durumu Şekil 3'de paylaşılmıştır.

PMMoV son y1llarda biber üretim alanlarında büyük problemler oluşturmaktadır. Özellikle Çağlar ve ark. (2012)'nın yılında yapılan çalışmada $L 3$ geni vasıtasıyla PMMoV için sağlanan dayanıklılığın kırılmasının rapor edilmesiyle birlikte bu hastalık ile mücadelede kullanılacak tek dayanıklılık kaynağı olarak Capsicum chacoense'den elde edilen L4 geni üzerinden 
çalışmalara devam edilmiştir. L4 geni vasıtasıyla sadece PMMoV'ye karşı değil aynı zamanda Tobamoiırus grubuna ait ToMV, TMV gibi diğer virüslere karşı1da dayanıklılık sağlanabildiği belirtilmiştir (Boukema 1984). L4 gen aktivitesinin kırılmış olma ihtimali bu virüslere karşı elimizdeki en güçlü silahımızı kaybedebileceğimiz anlamına gelmektedir. $\mathrm{Bu}$ yüzden $L 4$ gen aktivitesini belirlemeye yönelik en başarılı moleküler markırın tespit edilmesi, PMMoV'nin bitkiler üzerinde oluşturdukları reaksiyonlar ile birlikte değerlendirilmesi $L 4$ geninden sağlanan dayanıklılı̆̆ın kırılıp kırılmadığı konusundaki şüpheleri aydınlatmanın en önemli adımını oluşturmaktadır.

L4 geni içeren test bitkilerinin PMMoV izolatına gösterdiği tepkiler çalışma dönemi boyunca hem fenotipik hem de genotipik kriterlere göre değerlendirilmiştir. Bitkilerin sergilemiş oldukları fenotipik ve genotipik reaksiyonlar birleştirildiğinde geriye belirlenmesi gereken bir diğer konu L4 genini en iyi belirleyen markırların tespitidir. Bunun için daha önceden rapor edilmiş olan L4SC340, AP-7/AP-8, 060I2END, 087H3T7, P118/P119 markırları seçilerek en doğru yanıtı veren markır belirlenmeye çalışılmıştır. Test bitkilerinin PMMoV'e karş1 gösterdikleri tepkiler 5 farklı deneme kurularak gözlemlenmiştir ve her deneme sonucunda $L 4$ geni içeren bitkilerin PMMoV ile bulaşmadığı hassas çeşitlerin ise PMMoV ile bulaştı̆̆ 1 doğrulanmıştır. L4 genin dayanıklılık yanıtlarının çok yüksek olduğu birçok araştırmacı tarafindan rapor edilmesi ve Antalya bölgesinde PMMoV'ye ait şikâyetlerin artması neticesinde bizleri en doğru sonuca ulaştıracak olan moleküler markırı bulmaya yönlendirmiştir. $\mathrm{Bu}$ amaç doğrultusunda 6 test bitkisine, biberde $L 4$ geninin tespitinde yayınlanmış ve kabul gören primerler; L4SC340 (Kim ve ark. 2008), AP-7/AP-8 (Matsunaga ve ark. 2003), 060I2END- 087H3T7 (Yang ve ark. 2009), P118/P119 (Lefebvre ve ark. 2002) ile test edilmiştir ve sonuçlar mekanik inokulasyon sonuçları ile birleştirilmiştir. Moleküler markırlar ve klasik test sonuçları Çizelge 3'de özetlenmeye çalışılmıştır.
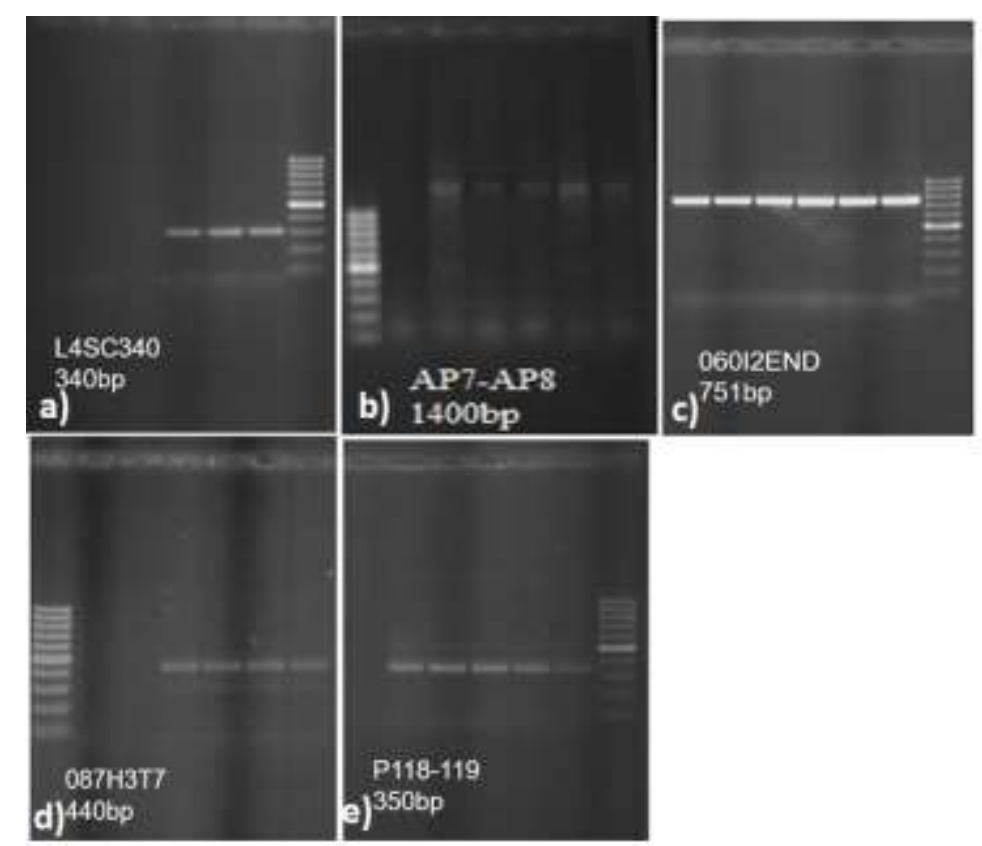

Şekil 1. L4 primerlerine ait jel görüntüler, a) L4SC340 primerine ait jel görüntüsü, b) AP7-AP8 primerine ait jel görüntüleri, c) 06012END primerine ait jel görüntüsü, d) $087 \mathrm{H} 3 \mathrm{T7}$ primerine ait jel görüntüsü, e) P118-P119 primerlerine ait jel görüntüsü.

Figure 1. Gel images of L4 primers, a) Gel image of L4SC340 primer, b) Gel images of AP7-AP8 primer, c) Gel image of primer 06012END, d) Gel image of primer 087H3T7, e) Primers of P118-P119 gel image.
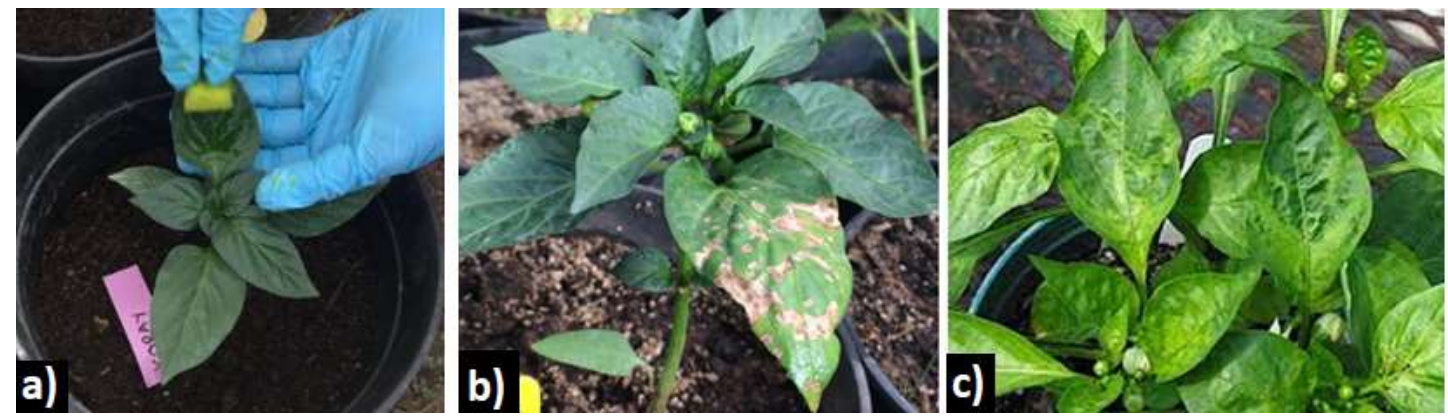

Şekil 2. Mekanik inokulasyon sonrasında bitkilerde meydana gelen simptomlar; a) Test bitkilerine mekanik inokulasyon işlemi b) $L 4$ geni bulunan çeşitlerde meydana gelen hipersensitif reaksiyonlar c) Hassas bitkiler üzerinde meydana gelen ilk simptomlar.

Figure 2. Symptoms in plants after mechanical inoculation; a) Mechanical inoculation to test plants b) Hypersensitive response in varieties with L4 gene c) Initial symptoms on susceptible plants. 
Çizelge 2. PMMoV-Kum izolatı için oluşturulan deneme planı.

Table 2. Test plan for PMMoV-Kum isolate.

\begin{tabular}{|c|c|c|c|c|c|}
\hline Deneme Sayısı & Deneme Süresi & Ortalama Sicaklık & İnokulasyon Tarihleri & Moleküler Test Tarihleri & Yer \\
\hline I & $\begin{array}{l}\text { Bş:23.09.18 } \\
\text { Bt:01.12.18 }\end{array}$ & $15.8^{\circ} \mathrm{C}$ & $\begin{array}{c}\text { I:24.09.17 } \\
\text { II:04.09.17 } \\
\text { III: } 14.10 .17 \\
\text { IV:25.10.17 } \\
\text { V:05.11.18 }\end{array}$ & 10.12 .18 & Sera \\
\hline II & $\begin{array}{l}\text { Bş:10.01.18 } \\
\text { Bt:25.03.18 }\end{array}$ & $11.2^{\circ} \mathrm{C}$ & $\begin{array}{l}\text { I: } 12.01 .18 \\
\text { II: } 21.01 .18 \\
\text { III:03.02.18 } \\
\text { IV:13.02.18 } \\
\text { V:23.02.18 }\end{array}$ & 27.03 .18 & Sera \\
\hline III & $\begin{array}{l}\text { Bş:01.04.18 } \\
\text { Bt:27.07.18 }\end{array}$ & $25-28^{\circ} \mathrm{C}$ & $\begin{array}{l}\text { I:02.04.18 } \\
\text { II:05.04.18 } \\
\text { III: } 15.04 .18 \\
\text { IV:25.04.18 } \\
\text { V.06.05.18 }\end{array}$ & 13.07 .18 & İklimlendirme Odası \\
\hline IV & $\begin{array}{l}\text { Bş:01.07.18 } \\
\text { Bt: } 25.10 .18\end{array}$ & $25-28^{\circ} \mathrm{C}$ & $\begin{array}{l}\text { I:02.07.18 } \\
\text { II:06.07.18 } \\
\text { III: } 14.08 .18 \\
\text { IV:27.08.18 } \\
\text { V:05.10818 }\end{array}$ & 24.10 .19 & İklimlendirme Odası \\
\hline $\mathbf{V}$ & $\begin{array}{l}\text { Bş:02.11.18 } \\
\text { Bt:30.03.19 }\end{array}$ & $11.3^{\circ} \mathrm{C}$ & $\begin{array}{c}\text { I:03.11.18 } \\
\text { II:08.11.18 } \\
\text { III:18.11.18 } \\
\text { III:01.012.18 } \\
\text { IV:11.01.19 } \\
\text { V:21.01.19 }\end{array}$ & 25.03 .19 & Sera \\
\hline
\end{tabular}

Çizelge 3. 6 adet biber çeşidinin 5 farklı primer kombinasyonuna ait PCR çalışması sonuçları. (+, turkuaz) $L 4$ var, (-, gri) $L 4$ yok.

Table 3. PCR amplification results of 5 different primer combinations of 6 pepper varieties. (+, turquoise) $L 4$ exists, (-, gray) $L 4$ absent.

\begin{tabular}{|c|c|c|c|c|c|c|}
\hline Primer / Biber Çeşidi & B1 & L4B2 & L4B3 & L4B4 & L4B5 & L4B6 \\
\hline L4SC340 & - & - & - & + & + & + \\
\hline AP-7/AP-8 & - & + & + & + & + & + \\
\hline 060I2END & + & + & + & + & + & + \\
\hline 087Н3Т7 & - & - & + & + & + & + \\
\hline P118/P119 & - & + & + & + & + & + \\
\hline
\end{tabular}

Çalışma esnasında elde etmeyi istediğimiz önemli verilerden biri $L 4$ geninin varlığını en doğru şekilde bize sunan moleküler markırları belirleyebilmektir. $\mathrm{Bu}$ verilerin elde edilmesi L4 geni kullanılarak yürütülen dayanıklılık 1slahı çalışmalarında araştırmacılara büyük kolaylık sağlayacaktır. Aynı zamanda da $L 4$ dayanımının etkili bir şekilde devam edip etmediğinin belirlenmesine yönelik bir adımı oluşturmaktadır. $\mathrm{Bu}$ amaç için $L 4$ geni içeren ve içermeyen bitkilerin PMMoV'ye karşı gösterdikleri tepkiler belirlenmiştir. L4 geni içeren bitkiler PMMoV enfeksiyonlarına HR yanıtları ile karşı koyarak enfeksiyonu önlemesi bu genin aktivitesinin hala sağlandığını bizlere göstermiştir. L4B2, L4B3, L4B4, L4B5 bitkileri üzerinde herhangi bir PMMoV enfeksiyonu meydana gelmediği hem gözlemlerle hem de RT-PCR sonuçları ile doğrulanmıştır. $\mathrm{B} 1$ bitkisinde ise $\mathrm{PMMoV}$ enfeksiyonuna ait simptomlar hem gözle görülür şekilde fark edilmiş hem de RTPCR sonuçları ile bu simptomların sadece PMMoV ait olduğunu doğrular nitelikte olmuştur. $\mathrm{Bu}$ veriler doğrultusunda moleküler markırlarında L4B2, L4B3, L4B4, L4B5 bitkilerinin $L 4$ genini içerdiği $\mathrm{B} 1$ bitkilerinin ise $L 4$ geninden yoksun olduğu sonucunun elde edilmesi gerekmektedir. $L 4$ geni için denenen 5 primer çiftinden sadece P118/P119 ve AP-7/AP-8 primer çiftleri elde ettiğimiz fenotip verileri ile birebir uyuştuğu sonucuna varılmıştır. L4 geni bulunmayan B1 çeşidinde, 060I2END primerine göre pozitif sonuç vermesinin yanıltıcı olabileceği belirlenmiştir. Ayrıca $L A$ geni bulunduğuna emin olduğumuz L4B2 ve L4B3 çeşitleri içinde, L4SC340 primerine göre negatif sonuç verip, AP-7/AP-8primerine göre pozitif sonuç vermesi de bu iki primerin birbirleri ile tutarlı sonuçlar vermediği dolayısıyla da anlam karmaşasına yol açabileceği düşünülmektedir. Elde edilen bu bulgular, L4 geninin kırılıp kırılmadığı tartışmasına verilebilecek cevabı bizlere sunmaktadır. Başarı oranı düşük olan markırların kullanılması L4 gen varlığının bitkilerde yanlış belirlenmesine, dolayısıyla L4 geni bulunmayan çeşitlerin arazi denemelerinde, PMMoV ile enfekteli bitkilerin var olmasına neden olmuştur. Yanlış primer kullanımının ülkemiz için; emek, zaman ve kaynak israfına yol açtı̆̆ını unutmamak gerekir. Bu primerlerin birbirleri ile neden tutarlı cevaplar vermediğinin irdelenmesi de başka bir çalışma ile aydınlatılması gerekmektedir.

Moleküler markırların başarısını etkileyen unsurlardan biri de bu primerlerin aday gen olan $L 4$ genine ne kadar yakınlıkta konumlandığ 1 bilgisidir. Denemede kullanılan L4SC340 L4 genine $1.8 \mathrm{cM}$ yakınında konumlandığ (Kim ve ark. 2008), AP7/AP-8 primerlerinin L4 genine olan yakınlığının $1.5 \mathrm{cM}$ yakınında olduğu (Matsunaga ve ark. 2003), 087H3T7 primerinin ise gene olan uzaklığının $0.7 \mathrm{cM}$ yakınında konumlandiğı rapor edilmiştir (Yang ve ark. 2009). Bu araştırmacıların verileri dikkate alındığında en başarılı primerin Yang ve ark. (2009) y1lında geliştirdikleri 087H3T7 primeri olması beklenmektedir. Buna karşıllk kurmuş olduğumuz beş deneme ve bitkilerin PMMoV ile bulaşık olma durumları 

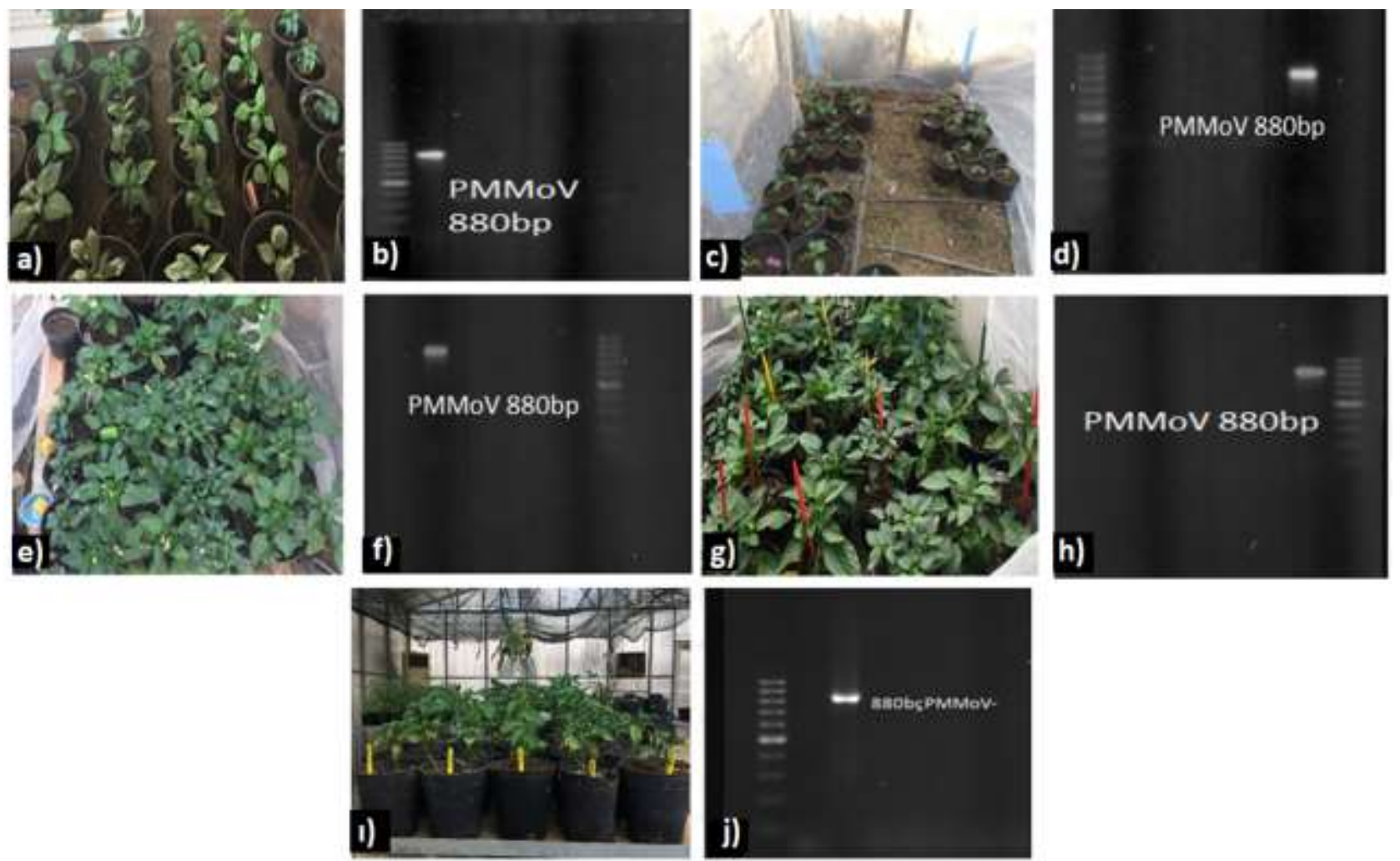

Şekil 3. PMMoV inokulasyonun farklı dönemlerde ve farklı ortamlarda mekanik inokulasyonuna ait veriler; a) 23.09.18-01.12.18 tarihleri arasında kurulan deneme, b) 23.09.18-01.12.18 denemesinde kullanılan test bitkilerinin PMMoV ile enfekteli olduğuna ait RT-PCR sonuçları, c) 10.01.18-25.03.18 tarihleri arasında kurulan deneme, d) 10.01.18-25.03.18 denemesinde kullanılan test bitkilerinin PMMoV ile enfekteli olduğunun RT-PCR ile doğrulanması, e) 01.04.18-27.07.28 tarihleri arasında kurulan deneme, f) 01.04.18-27.07.28 denemesinde kullanılan test bitkilerinin PMMoV ile enfekteli olma durumunun RT-PCR ile doğrulanması, g) 01.07.18-25.10.18 tarihlerinde kurulan deneme, h) 01.07.18-25.10.18 tarihlerinde kullanılan test bitkilerinin PMMoV ile enfekteli olma durumunun RT-PCR ile doğrulanmas1, 1) 02.11.1930.03.19 tarihinde kurulan deneme, j) 02.11.19-30.03.19 tarihleri arasındaki denemede kullanılan test bitkilerinin PMMoV ile enfekteli olma durumunun RT-PCR ile doğrulanmasi.

Figure 3. Data of mechanical inoculation of PMMoV inoculation at different periods and in different environments; a) The experiment established between 23.09.18-01.12.18, b) RT-PCR results showing that the test plants used in the experiment 23.09.18-01.12.18 were infected with PMMoV, c) The experiment established between 10.01.18-25.03.18 d) Confirmation that the test plants used in the 10.01.18-25.03.18 experiment were infected with PMMoV by RT-PCR, e) the experiment established between 01.04.18-27.07.28, f) the test used in the experiment 01.04.18-27.07.28 Verification of PMMoV-infected plants by RT-PCR, g) Trial established on 01.07.18-25.10.18; J) Verification of PMMoV infection of test plants used in the experiment between 02.11.19-30.03.19 by RT-PCR.

değerlendirildiğinde en başarılı primerin Matsunaga ve ark. (2003)'da geliştirdikleri AP-7/AP-8 primeri olduğu belirlenmiştir. $087 \mathrm{H} 3 \mathrm{~T} 7$ primerinin kurmuş olduğumuz denemlerde L4B2 bitkisinde herhangi bir PMMoV enfeksiyonuna rastlamadığ 1 ve AP-7/AP-8, 0602I2END, P118/P119 primerleri ile $L 4$ geninin varlığ tespit edilmiştir. Bu sonuçlar birleştirildiğinde $087 \mathrm{H} 3 \mathrm{~T} 7$ primerinin başarı oranını düşüren bir parametre olduğu kanısına varılmaktadır. Daha geniş populasyon aralığında bu primerlerin başarı oranlarının irdelenmesi araştırmacıların doğru sonuçlara ulaşması için atılacak önemli bir adımdır. Ayrıca Yang ve ark. (2009) L3 ve L4 markırları arasındaki genetik uzaklığın C.annum/C.chinense veya $C$. annum/C. chacoense arasinda meydana gelen melezler arasında farklılıklar gösterebileceğini belirtmişlerdir. Melezler arasındaki farklılıkların bu genlerin çalışma aktivitelerinde herhangi bir farklılık meydana getirip getirmediğinin belirlenmesi gerekmektedir.

$L$ genleri için farklı sıcaklıklara bağlı aleller L1a, L1c ve $\mathrm{L} 2 \mathrm{~b}, C$. annuum $c v$. KC780, $C$. chinense KC667 ve $C$. baccatum PI 439381-1-3 üzerinde tanımlanmıștır (Tomita ve ark. 2011). L4 gen aktivitesinin farklı sıcaklıklar gibi değişik çevre etmenleri tarafindan etkilenip etkilenmediğinin belirlenmesi amacıyla çalışmamızın, biyolojik test kısmı bir yılın tüm zaman dilimine dağıtılarak ve farklı ortamlar (sera ve iklimlendirme) temel alınarak planlanmıştır. Bu planlamanın amac1 sicaklık etkilerinin monogenik dominant gen olarak belirtilen (Boukema 1983; Van Duin 1998) L4 geninin sıcaklığa bağlı olarak gösterdiği davranıșların belirlenmesi ve son yıllarda Antalya'daki biber üretim alanlarında neden olan $\mathrm{PMMoV}$ enfeksiyonlarında sıcaklık faktörünün $L 4$ genine bağlı olarak davranışındaki etkilerindeki payının belirlenmesidir. Bir y1 boyunca farklı mevsimlerde planlamış olduğumuz biyolojik test sonuçlarında L4B2, L4B3, L4B4, L4B5, L4B6 bitkilerinde herhangi bir simptomun oluşmaması hem makroskobik gözlemlerle hem de moleküler yöntemler ile belirlenmiștir. Bu veriler birleştirildiğinde PMMoV-Kum izolatının epidemilerinde sicaklı etmeninin önemi olmadığ belirlenmiştir.

PMMoV-Kum izolatının bitkiler üzerindeki gözlemleri ve moleküler çalışmaları birleştirildiğinde geriye tartışılması 
gereken diğer konu bu izolatın dünya izolatları ile arasındaki filogenetik ilişkinin belirlenmesidir. Bu izolatın Velasco ve ark. (2002)'nin geliştirdiği primerler kullanılarak RT-PCR çalışmaları ile PMMoV'ye ait olduğu doğrulanmıştır. $\mathrm{Bu}$ izolatın evrimsel ilişkileri hakkında yorumlarda bulunmak ve göç haritası hakkında ipuçları alabilmek için sekans hizmetleri alınmış ve filogenetik analizleri gerçekleştirilmiştir. Sekans hizmetleri sonucunda 793 bp uzunluğunda PMMoV'ye ait genom parçası elde edilmiştir. Elde edilen PMMoV-Kum izolatına ait sekans bilgileri NCBI (National Center for Biotecnology Information) veri tabanı üzerinde MK806437aksesyon numarası ile kayıt edilerek araştırmacıların kullanımına sunulmuştur.Bu kısa sekans parçası PMMoV-Kum izolatının BLAST Analizlerinde (NCBI veri tabanında nükleotid bazında yapılan kıyaslama) en yakın ilişkiyi \%100 oranınıda KC288153 izolatı ile kurduğu görülmüştür. KC288153 izolatı 2009 y1lında Sirbistandan elde edilen PMMoV'ye ait bir sekanstır (Milosevic ve ark. 2012).Bu araştırma grubu rapor ettikleri PMMoV sekansının k1lıf proteinine özgü bölgeyi amplifiye ederek yaptıkları kıyas analizlerinde bu izolatın L3 geninin sağladığ 1 dayanımı kıramayan P1.2 patotipine ait olduğunu belirtmişleridir.

PMMoV-Kum izolatının filogenetik analizi için Türkiye, Sırbistan, Japonya, Çin, Kanada, Güney Kore, Brezilya, Tunus, Amerika Birleşik Devletleri, Hindistan, İspanya, Venezuela, Avustralya'nın dahil olduğu 13 ülke filogenetik analize dahil edilmiştir. Çizelge 4'de filoegenetik analize tabi tutulan izolatlara ait bilgiler paylaşılmıştır.Filogenetik ağaç oluşturulurken dikkat edilen önemli bir unsur ise konukçu aralığı olmuştur. Filogenetik analize dâhil edilen 16 izolatın konukçuları incelendiğinde 9 tanesi biber, 3 tanesi ise yabancı otlardan oluşmaktadır. Oluşturulan Filogenetik ağaç Şekil 4'de paylaşılmıştır.

Filogenetik ağaca ait veriler incelendiğinde PMMoV'e ait izolatların iki ana gruba bağlı olarak dallandığı görülmektedir. I. grup olarak nitelendirilen kümede genel olarak $L 4$ ve $L 3$ dayanımını kıran P1.2.3. ve P1.2.3.4 izolatların var olduğu görülmekte iken ülkemizin Antalya-Kumluca bölgesinden elde edilen PMMoV-Kum izolatınında dâhil olduğu II. gruba ait olduğu belirlenmiştir. 2016-2017 yılında Antalya-Kumluca bölgesinden elde edilen izolatların Grup II'de yer alması bu izolatın L4 dayanımını kıran bir patotipe ait olmadığını sonucunu moleküler ve klasik testlemelerden sonra filogenetik analizi ile de doğrulanmasına imkân sağlamıştır.

Ülkemizde son yıllarda biber üretim alanlarında problem olan PMMoV patotipinin L3 genini kıran P1.2.3 patotipi olduğu düşünülmektedir. Çağlar ve ark. (2012)'nın yılında yaptıkları çalışmalarında L3 dayanımını kıran izolatın ülkemizde varlığından söz etmişlerdir. Şuan ki biber üretim alanlarında $L 4$ dayanımını kıran izolata rastlanmamıştır. Ama ülkemizde P1, P1.2 patotiplerinin varlı̆̆ veya yokluğuna dair bir çalışma da mevcut değildir. Choi ve ark. (2013, 2014) Kore'de gerçekleştirdikleri çalışmalarında $\mathrm{P} 1.2$ ve $\mathrm{P} 1.2 .3$ patotiplerinin bulunabildiğini belirtmiş̧lerdir. Antignus ve ark. (2008) ise İsrail'de benzer bir çalışma yürüterek P1.2 ve P1.2.3 patotiplerinin varlığını önceden belirlemişlerdir. Arazi sürveylerinde PMMoV ile benzer özellikler sergileyen örnekleri toplayıp RT-PCR yöntemi kullanarak PMMoV ile enfekteli olduğunu doğrulamışlardır. Elde edilen kılıf proteininin tüm nükleotid dizilimlerini kullanarak bu protein alanı içerisinde meydana gelen bir mutasyonun P1.2.3.4 patotipini meydana getirdiği sonucuna varmışlardır. Genda ve ark. (2007) Japonya'da gerçekleştirdikleri çalışmalarında benzer yöntemleri kullanarak PMMoV'in agresiflik derecesi en yüksek patotipi olarak P1.2.3.4 patotipinin varlığını rapor etmişlerdir. Ülkemizde 2017-2018 üretim dönemi içerisinde sıklıkla karşılaşılan PMMoV izolatının klasik testlemeler ve moleküler yöntemler ile L4 dayanımını kıran bir patotip olmadığı belirlenmiştir.

Çizelge 4. Filogenetik analizler için kullanılan izolatlara ait bilgiler.

Table 4. Information on isolates used for phylogenetic analysis.

\begin{tabular}{|c|c|c|c|c|c|}
\hline Sira & NCBI numarası & Patotip & Ülke & Konukçu & Benzerlik oranları (\%) \\
\hline 1 & $\begin{array}{c}\text { MK806437 } \\
\text { PMMoV-Kum }\end{array}$ & & Türkiye & Capsicum аппиит & \\
\hline 2 & KC288153 & & Sirbistan & Capsicum аппиит & 100.00 \\
\hline 3 & AB276030 & L4BV & Japonya & Yeşil biber & 99.75 \\
\hline 4 & AB254821 & Patotip P1.2 & Japonya & & 99.75 \\
\hline 5 & KP345899 & & Çin & Capsicum аппиит & 97.60 \\
\hline 6 & KU311159 & & Kanada & & 99.12 \\
\hline 7 & KR108206 & & Güney Kore & Rorippa palustris & 97.73 \\
\hline 8 & AB550911 & BR-DF01 & Brezilya & & 97.73 \\
\hline 9 & KR108207 & & Güney Kore & Leonurus sibiricus & 97.60 \\
\hline 10 & EF061142 & & Tunus & Biber & 97.60 \\
\hline 11 & MH063882 & & $\mathrm{ABD}$ & Şili biber & 97.23 \\
\hline 12 & KJ631123 & & Hindistan & Capsicum аппиит & 97.23 \\
\hline 13 & LC082100 & P3 & Güney Kore & Acı biber & 94.18 \\
\hline 14 & KX063611 & $\mathrm{P} 1.2$ & İspanya & Biber & 97.73 \\
\hline 15 & KU312319 & & Venezuela & & 97.35 \\
\hline 16 & MH427282 & & Avustralya & Apis mellifera & 97.35 \\
\hline
\end{tabular}




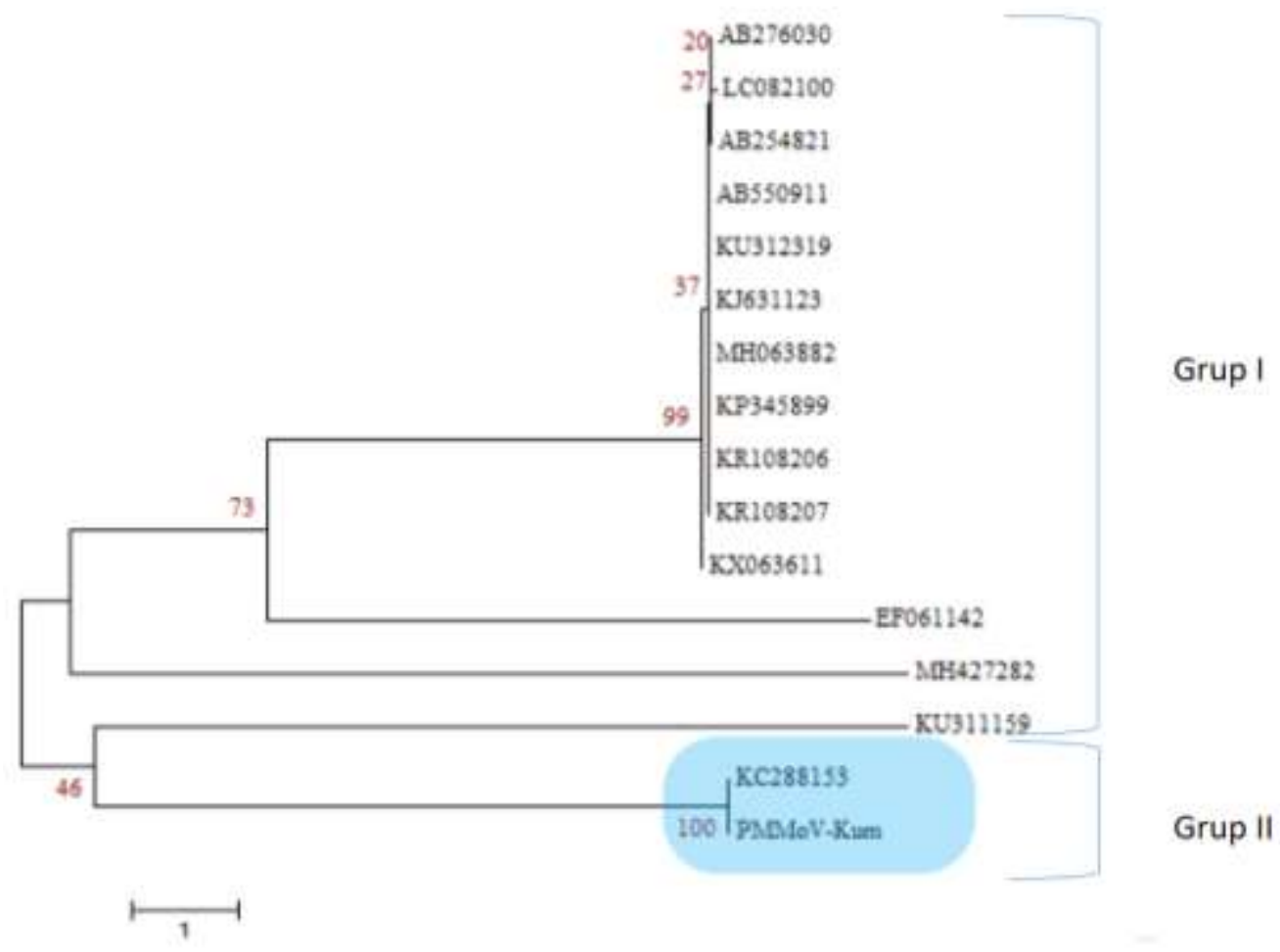

Şekil 4. PMMoV-Kumluca izolatına ait filogenetik analizler.

Figure 4. Phylogenetic analysis of PMMoV-Kum isolate.

PMMoV'nin 2019 yılında ülkemizde L4 dayanıklılık genini kıran izolatın bulunmaması ilerleyen dönemlerde karşımıza çıkmayacağı anlamına gelmemektedir. Dünyanın farklı bölgelerinde $L 4$ genini kıran bu izolatın varlığına dair raporlar mevcuttur. $\mathrm{Bu}$ raporların genel özellikleri dünyanın farklı bölgelerinde PMMoV'nin farklı patotiplerinin karşımıza çıkabileceğidir. $\mathrm{Bu}$ araştırmalardan elde ettiğimiz sonuç ise okları karantina uygulamalarına çevirmektedir. Biber üretim alanlarının yetiştirilme periyodu boyunca başta TSWV, PVY, CMV, TMV, PMMoV gibi birçok virüs tarafından tehdit altındadır. Özellikle TSWV'nin dayanıklılığı kıran ırkının varlığı yetiştirilme alanlarının büyük bir sorun olarak karşımıza çıkmaktadır. $\mathrm{Bu}$ hastalık ile mücadelede henüz dünyada bir çalışmanın varlığının söz konusu olmamasından dolayı, yakın gelecekte çözümü olmayan PMMoV'in L4 genini kıran ırkının ülkemize girmemesi için dikkat edilmesi gereken bir konudur. $\mathrm{Bu}$ amaç için karantina uygulamalarına ağırlık verilmesi gerekliliğini ortaya koymaktadır. Ayrıca Tobamovirüsler toprakta uzun süre kalıcılığını sürdürebilmekte ve kökler geliştikçe açılan küçük yaralardan giriş yaparak enfeksiyonlarını meydana getirebilmektedir. Bu konu göz önünde tutulduğunda toprak dezenfeksiyonun önemini artırmaktadır. Özellikle 2009 yılından bu yana toprak dezenfeksiyonlarında tercih edilen metil bromid'in yasaklanması ile toprak kökenli patojenlerin oranında artışlar görülmüştür. Alternatif çevre dostu kimyasal uygulamaları belirlense de üreticilerin bu konu hakkında bilinçlendirilmeleri ve bu uygulamaların geliştirilmesi gerekmektedir.

\section{Sonuç}

Son yıllarda biber üretim alanlarında virüs hastalıklarının görülme insidansında artışlar meydana gelmiştir. Üretim alanlarında kültürel-fiziksel ve kimyasal kontrol yöntemlerinin bilinçsiz yapılması virüslerin ve onlara vektörlük yapan etmenlerin bu alanlara erişimini kolaylaştırmıştır. Son yıllarda Antalya'da özellikle Kumluca ilçesinde biber üretim alanlarında s1k rastlanan virüslerden biri olarak karşımıza PMMoV'nin çıkması ve virüsün diğer Tobamovirüsler gibi tohumla taşınması nedeniyle ciddiye alınması gereken bir problem olduğunu bizlere göstermektedir. Bu bağlamda incelenmesi gereken bir diğer konunun PMMoV ile mücadelede $L 4$ gen aktivitesinin enfeksiyonlara verdiği cevapların nitelendirilmesi gerekliliğidir. Yapılan biyolojik testlemeler ve moleküler analizler neticesinde L4 geni tarafindan sağlanan dayanıklılığın hala etkin olduğu sonucuna varılmıştır. Ayrıca L4 tanılamaya yönelik en etkili markırlar AP-7/AP-8 ve P118-P119 markırları olarak belirlenmiştir. Doğru markır seçiminin doğru tanılamayı sağlayacağından $L 4$ genine yönelik çalışmalarda bu verilerin önemi oldukça büyüktür. Ayrıca PMMoV-Kum izolatının nükleotid bilgileri elde edilerek NCBI (Uluslar Arası Gen bankası-MK806437) kayıt edilmiş ve filoegenetik analizleri gerçekleştirilmiş ve dünya izolatları arasında konumu belirlenmiştir.

\section{Kaynaklar}

Antignus Y, Lachman O, Pearlsman M, Maslenin L, Rosner A (2008) A New Pathotype of Pepper mild mottle virus (PMMoV) Overcomes the L4 Resistance Genotype of Pepper Cultivars. Plant Disease 92(7): 1033-1037.

Berzal-Herranz A, de la Cruz A, Tenllado F, Díaz-Ruíz JR, López L, Sanz AI, Vaquero C, Serra MT, García-Luque I (1995) The Capsicum L3 gene-mediated resistance against the Tobamoviruses is elicited by the coat protein. Virology 209: 498-505.

Boukema IW (1980) Allelism of genes controlling resistance to TMV in Capsicum L. Euphytica 29: 433-439. 
Boukema IW (1983) Research on the location of the gene for resistance to TMV in Capsicum chacoense Hunz. and male sterility in progenies from the cross $C$. chacoense $\times C$. annuum L. Proceedings $\mathrm{V}^{\text {th }}$ Meeting Capsicum and Eggplant Working Group of Eucarpia, Bulgaria, p. 84-87.

Boukema IW (1984) Resistance to TMV in Capsicum chacoense Hunz. is governed by an allele of the L-locus. Capsicum Newsletter 3: 47 48.

Choi GS, Choi SK, Cho JD, Cho IS (2013) A pathotype of Pepper Mild Mottle Virus causing necrotic spot symptoms in paprika fruit. Research in Plant Disease 19: 124-127.

Choi GS, Choi SK, Cho IS, Kwon SJ (2014) Resistance screening to Pepper Mild Mottle iVrus pathotypes in paprika cultivars. Research in Plant Disease 20: 299-302.

Csillery G, Tobias I, Rusko J (1983) A New Pepper Strain of Tomato Mosaic Virus. Acta Phytopathologica Academiae Scientiarum Hungaricae 18: 195-200.

Cağlar BK, Fidan H, Elbeaino T (2012) Detection and Molecular Characterization of Pepper Mild Mottle Virus from Turkey. Journal of Phytopathology 161(6): 434-438.

FAOSTAT (2018) Statistical database. http://www. fao.org/faostat/en/\#data/QC. Accessed 11 May 2018.

Fidan H, Sarı N (2019) Molecular Characterization of ResistanceBreaking Tomato Spotted Wilt Virus (TSWV) Isolate Medium Segment in Tomato. Applied Ecology and Environmental Research 17(2): 5321-5339.

Genda Y, Kanda A, Hamada H, Sato K, Ohnishi J, Tsuda S (2007) Two amino acid substitutions in the coat protein of Pepper mild mottle virus are responsible for overcoming the $L 4$ gene-mediated resistance in Capsicum spp. Phytopathology 97: 787-793.

Hall TA (1999) BioEdit: a user-friendly biological sequence alignment editor and analysis program for Windows 95/98/NT. Oxford University Prees, Nucleic Acids Syposium Series No.41: 95-98.

Janzac B, Fabre MF, Pallo1x A, Moury B (2009) Phenotype and spectrum of action of the Pvr4 resistance in pepper against potyviruses, and selection of virulent variants. Plant Pathology 58: 443-449.

Kim HJ, Han JH, Yoo JH, Cho HJ, Kim BD (2008) Development of a sequence characteristic amplified region marker linked to the L4 locus conferring broad spectrum resistance to tobamoviruses in pepper plants. Molecules and Cells 25: 205-210.

Kumar S, Udaya AC, Nayaka SC, Lund OS, Prakas HS (2011) Detection of Tobacco mosaic virus and Tomato mosaic virus in pepper and tomato by multiplex RT-PCR. Letter in applied Microbiology 359-363.
Lefebvre V, Pflieger S, Thabuis A, Caranta C, Blattes A, Chauvet JC, Daubeze AM, Palloix A (2002) Towards the saturation of the pepper linkage map by alignment of three intraspecific maps including known-function genes. Genome 45(5): 839-854.

Matsunaga HT, Saito M, Hirai T, Yoshida T (2003) DNA markers linked to pepper mild mottle virus (PMMoV) resistant locus (LA) in Capsicum. Japanese Society for Horticultural Science 72: 218-220.

Milosevic D, Stankovic I, Bulajic A, Nikolic Z, Ignjatov M, Krstic B (2012) Molecular characterization of Pepper mild mottle virus in Serbia. Genetıka 47(2): 651-663.

Pernezny K, Roberts PD, Murphy JF, Goldberg NP (2003) Compendium of Pepper Diseases. St. Paul, Minnedota: The American Phytopathological Society, p. 73.

Rast ATB (1988) Pepper tobamoviruses and pathotypes used in resistance breeding. Capsicum Newsletter 7: 20-23.

Sawada H, Takeuchi S, Matsumoto K, Hamada H, Kiba A, Matsumoto M, Watanabe Y, Suzuki K, Hikichi Y (2005) A new Tobamovirusresistance gene, Hk, in Capsicum annuum. Japanese Society for Horticultural Science 74: 289-294.

Scholthof KBGS, Adkıns H, Czosnek P, Palukaitis E, Jacquot T, Hohn B, Hoh K, Saunders T, Candresse P, Ahlquist C, Foster GD (2011) Top 10 plant viruses in molecular plant pathology. Molecular Plant Pathology 12: 938-954.

Tomita R, Ken-Taro S, Hiroyuki M, Sakamoto M, Murai J, Kiba A, Hikichi Y, Suzuki K, Kobayashi K (2011) Genetic basis for the hierarchical interaction between Tobamovirus spp. and L resistance gene alleles from different pepper species. Molecular PlantMicrobe Interactions 24: 108-117.

TUIK (2018) Statistical database. http://www.tuik.gov.tr/ PreTablo.do?alt_id=1001. Accessed 01 May 2018.

Van Duin PJW (1998) $X^{\text {th }}$ EUCARPIA Meeting on Genetics and Breeding of Capsicum \& Eggplant, Avignon, France.

Velasco L, Janssen D, Ruiz-Garcia L, Segundo E, Cuadrado IM (2002) The complete nucleotide sequence and development of a diferential detection assay for a pepper mild mottle virus (PMMoV) isolate that overcomes L3 resistance in pepper. Journal of Virological Methods 106(1): 135-140.

Wetter C, Conti M, Altschuh D, Tabillion R, Van Regenmortel MHV (1984) Pepper Mild Mottle Virus, a Tobamovirus infecting pepper cultivars in Sicily. Phytopathology 74(4): 405-410.

Yang HB, Liu WY, Kang WH, Jahn M, Kang BC (2009) Development of SNP markers linked to the L locus in Capsicum spp. by a comparative genetic analysis. In Molecular Breeding 24(4): 433446. 